\title{
The aulacid wasp fauna of Western Australia with descriptions of six new species
}

\author{
John T. Jennings ${ }^{1}$, Andrew D. Austin ${ }^{2}$ and Nicholas B. Stevens ${ }^{2}$ \\ ${ }^{1}$ Centre for Evolutionary Biology and Biodiversity, and School of Agriculture and Wine, Waite Campus, \\ The University of Adelaide, SA 5064, Australia. Email john.jennings@adelaide.edu.au \\ ${ }^{2}$ Centre for Evolutionary Biology and Biodiversity, and School of Earth and Environmental Science, \\ The University of Adelaide, SA 5005, Australia.
}

\begin{abstract}
This study describes for the first time the Aulacidae from Western Australia, a fauna that comprises six geographically isolated species. Three new species of Aulacus; $A$. douglasi, A. houstoni, and A. mcmillani, and three new species of Pristaulacus; $P$. curryi, $P$. davisi, and $P$. mouldsi, are described. At the same time, a key to genera and species is presented, along with a diagnosis for Aulacus and Pristaulacus, and notes on their taxonomic history and species diversity.
\end{abstract}

Key words: Evanioidea, Aulacidae, Aulacus, Pristaulacus, taxonomy, parasitic wasps.

\section{INTRODUCTION}

The Aulacidae is a family of parasitic wasps that are endoparasitoids of wood-boring wasps (Xiphydriidae) and beetles (Cerambycidae and Buprestidae) (Carlson 1979; Gauld and Bolton 1996; Smith 2001; Jennings and Austin in press), although there are no records of aulacids parasitising xiphydriid wasps in Australia. At various times the Aulacidae have been treated as a subfamily or group of the Evaniidae, or as a separate family, but all recent studies accord them family status (e.g. Naumann 1991; Mason 1993; Gauld 1995; Jennings and Austin 2000, in press; Smith 2001). They are included in the superfamily Evanioidea along with the Evaniidae and Gasteruptiidae, and are most closely related to the latter family (Jennings and Austin in press).

Although all Evanioidea are characterised by the high insertion of the metasoma on the propodeum, aulacids are readily distinguished from evaniids and gasteruptiids by the presence of fore wing cross-vein 2m-cu (Gauld and Bolton 1996), and cross-vein 3r-m (Konishi 1990), and the presence of a metapostnotum.

Smith (2001) provided a catalogue of the world aulacid fauna, and included 48 species of Aulacus Jurine, 106 species of Pristaulacus Kieffer, and two species of Panaulix Benoit. Both Aulacus and Pristaulacus are worldwide in distribution, but Panaulix is confined to sub-Saharan Africa.

The Australian fauna comprises some 40 described species (24 for Aulacus and 16 for
Pristaulacus) (Smith 2001; Jennings 2001; Jennings $e$ t al. in press), however, most descriptions are inadequate and date from the early part of the 20th Century. Even though modern collecting techniques such as malaise trapping have added significantly to the number of specimens held in museum and other collections, only one taxonomic study, that of Jennings et al. (in press), has been undertaken on the Australian fauna in the last 50 years.

This study is part of a project that aims to revise the Aulacidae of Australia, and for the first time treats the fauna of Western Australia which comprises three new Aulacus and three new Pristaulacus species.

\section{METHODS, TERMINOLOGY AND ABBREVIATIONS}

Specimens were observed under a Zeiss light microscope or using scanning electron microscopy (SEM). Specimens for SEM were first cleaned to remove obvious dirt and other debris and examined uncoated under a Phillips XL30 field emission SEM at $1 \mathrm{kv}$ and a spot size of three.

Terms for general morphology follow Jennings and Austin (1994), and that for wing venation follows the modified Comstock-Needham system after Sharkey (1988), but with some modifications, and using the nomenclature of van Achterberg (1979) for cells (Figures 1-2). Terms for surface sculpturing follow Harris (1979), and for male genitalia Crosskey (1951). Where morphometric 
measurements are based on more than one specimen, data are presented as the mean followed by the range. The length of the ovipositor is measured from the tip of the metasoma, and the length of the hind femur includes the prefemur (trochantellus).

The abbreviations for the institutions that are the repository of the specimens referred to in this paper are: Western Australian Department of Agriculture (WADA) and Western Australian Museum (WAM).

\section{SYSTEMATICS}

\section{Key to Western Australian species}

Most of the described Australian species of aulacids are from the higher rainfall, forested areas of the east coast. A key to continental fauna is not presented here because there are many undescribed species known in collections. However, because the six species are known only from Western Australia, a key is presented to facilitate their identification.

1. Hind tarsal claw not pectinate .......... Aulacus. 2 Hind tarsal claw pectinate ........... Pristaulacus. 4

2. Costal, basal, submarginal, and marginal cells of fore wing dark brown; large species, body length $16.5 \mathrm{~mm}$, excluding ovipositor A. douglasi, sp. nov.

Fore wing cells largely hyaline; smaller species, $<12.0 \mathrm{~mm}$ in body length, excluding ovipositor

3. Brown spot apically on marginal and submarginal cells of fore wing; lateral lobes of mesoscutum strigate; metasomal $\mathrm{T} 1$ and $\mathrm{T} 2$ broad when viewed dorsally

A. houstoni, sp. nov.

Wings entirely hyaline, apical spot on fore wing absent; lateral lobes of mesoscutum rugose; metasomal $\mathrm{T} 1$ and $\mathrm{T} 2$ narrow when viewed dorsally ........... A. mcmillani, sp. nov.

4. Fore wing vein $2-R s+M$ long and second discal cell elongate (see Figure 1); small species, 6.0 $\mathrm{mm}$ in body length, excluding ovipositor ..... P. curryi, sp. nov.

Fore wing vein $2-R s+M$ short and second discal cell more or less quadrate (see Figure 2); larger species, $>9.0 \mathrm{~mm}$ in body length, excluding ovipositor 5

5. Metasoma clavate; hind wing venation reduced, veins $\mathrm{R}+\mathrm{Rs}, \mathrm{M}+\mathrm{Cu}$ and $\mathrm{Cu}$ absent, $\mathrm{r}-\mathrm{m}$ and 2-M largely spectral (Figure 2) ......... $P$. davisi, sp. nov.

Metasoma ovate; hind wing venation not reduced, $\mathrm{R}+\mathrm{Rs}, \mathrm{M}+\mathrm{Cu}, \mathrm{Cu}, \mathrm{r}-2 \mathrm{~m}$ and $2-\mathrm{M}$ present (see Figure 1) .......P. mouldsi, sp. nov.
Aulacus Jurine, 1807

[For a complete taxonomic history of Aulacus see Jennings et al. (in press)]

\section{Diagnosis based on Australian species}

Eyes small, circular or subcircular, remote from the mandibles; antenna 14-segmented in female, 13 segmented in male; antennal insertions low on face, near lower margin of eyes; scape usually deeply convex ventrally in lateral view, much thicker than pedicel and flagellomeres; sub-antennal groove or depression to accommodate scape (e.g. Figure 8); metapostnotum between propodeum and metanotum as a distinct sclerotisation (Figures 1819); propodeum pyramidal, metasoma inserted high on the apex; metasomal $\mathrm{T} 1$ and $\mathrm{T} 2$ fused dorsally; hind coxa usually with groove or notch on inner lateral surface, the apposed grooves or notches forming an ovipositor guide; hind trochanter with a transverse trochanteral groove (Figure 16), prefemur (trochantellus) present (Figure 16); each tarsal claw with one basal tooth (sometimes difficult to see); fore wings not plicate at rest; fore wing vein $2 \mathrm{~m}$-cu present (Figure 1 ), vein $2 \mathrm{r}-\mathrm{m}$ usually present, largely spectral, vein $3 \mathrm{r}-$ $\mathrm{m}$ present, often largely spectral (Figure 1); ovipositor exserted, protruding well beyond apex of metasoma.

\section{Comments}

Aulacus currently includes all aulacids with nonpectinate hind tarsal claws and includes 51 species worldwide, 21 of which are endemic to Australia (Smith 2001; Jennings 2001; Jennings et al. in press).

\section{Aulacus douglasi sp. nov. \\ Figures 11, 16, 18, 29}

\section{Material Examined}

Holotype

․ "38-407, Wubin" "A. Douglas". (WAM). Right antennal flagellomeres 2-12, left antennal flagellomere 12, right fore tarsi, mid legs, right hind tibia and tarsi, and left ovipositor sheath missing.

\section{Female}

Length. $16.5 \mathrm{~mm}$, excluding ovipositor.

Colour. Body orange-red, with variable amounts of dark brown on mandibles, malar space, lateral mesoscutum, mesepisternum, mesepimeron, and metasomal T3 and T4; ovipositor brown; wings generally pale brown, costal, basal, submarginal and marginal cells darker brown.

Head. $1.24 \times$ wider than long when viewed dorsally; face rugose, pubescence short; distinct sub-antennal groove; frons with weak lateral medial carina above toruli, rugose, with short 
pubescence; vertex imbricate, with scattered short setae; gena imbricate, slightly rugulose ventrally near eye margin, with scattered short setae; posterior margin of head not concave in dorsal view; occipital carina absent; malar space $0.2 \times$ height eve; clypeus $4.0 \times$ as wide as high, margin sinuate, medial process present; distance from lateral ocellus to eye margin $0.86 \times$ distance between lateral ocelli; scape $2.1 \times$ length pedicel; first flagellomere $0.8 \times$ as long as scape, $1.0 \times$ as long as second flagellomere.

Mesosoma. Propleuron rugulose, pubescence short, ventro-lateral carina weak; pronotum without angular process, rugulose-imbricate; mesoscutum in lateral view rounded antero-dorsally, medial and lateral lobes rugose (Figure 11), with scattered short setae, admedial lines present, weak; scutellum and axillae rugulose (Figure 18); metapostnotum rugose, posterior margin scrobiculate (Figure 18); mesepisternum rugose, with short pubescence; mesepimeron broad, carinate; metapleuron coarsely rugose, with short pubescence; propodeum coarsely rugose, posterior margin scrobiculate; hind coxa rugose dorsally, smooth laterally, pubescence short laterally, ovipositor guide on inner surface, medial; hind trochanter weakly imbricate, with scattered short setae (Figure 16); hind prefemur on hind leg present; hind femur imbricate, with scattered short setae; hind tibia imbricate, pubescence short, with scattered stout emergent setae; hind femur $0.75 \times$ length hind tibia; hind tibia with ventro-apical pecten of short robust spines; hind tarsal segments 1-4 with ventro-apical pecten of short robust spines, segment $1,2.6 \times$ length segment 2 ; segment $2,1.6 \times$ length segment 3 ; segment $3,1.5 \times$ length segment 4 ; segment $4,0.7 \times$ length segment 5 ; hind tarsal claw $0.45 \times$ length segment 5 ; fore wing vein 2 Rs $+M$ long, second discal cell elongate, veins $2 r-m$ and $3 \mathrm{r}-\mathrm{m}$ largely spectral; hind wing venation complete, $\mathrm{R}+\mathrm{Rs}, \mathrm{M}+\mathrm{Cu}, \mathrm{Cu}, \mathrm{r}-\mathrm{m}$ and $2-\mathrm{M}$ present, with 2 hamuli.

Metasoma. Clavate, $1.75 \times$ length of mesosoma; T1 and T2 narrow, smooth; ovipositor $18.8 \mathrm{~mm}$.

Male

Unknown.

\section{Remarks}

Aulacus douglasi has a distinctive fore wing colouration in that the costal, basal, submarginal and marginal cells are dark brown, and this distinguishes it from the other Western Australian species. Although A. douglasi is similar to the fore wing colouration of $A$. festivus (Kieffer) from Queensland, the latter species differs in many ways including having more extensive black colouration on the head, body, and metasoma, and a smooth vertex. Aulacus douglasi is known only from the holotype locality, Wubin, Western Australia (Figure
29), and is named after the collector, Athol Douglas. Nothing is known of its biology.

Aulacus houstoni sp. nov.

Figures 1, 3, 9, 12, 19, 29

\section{Material Examined}

\section{Holotype}

q. "Fitzgerald River Nat. Pk. (NW Sector), Western Australia, 9-11 April 1982, T.F. Houston $444^{\prime \prime}$. (WAM).

\section{Female}

Length. $11.0 \mathrm{~mm}$, excluding ovipositor.

Colour. Body orange-brown except flagellomeres and ovipositor sheaths dark brown; mesoscutum, scutellum, axillae, metanotum, mesepisternum, metapleuron, propodeum, and metasomal T1 with variable amounts of dark brown; wings pale brown, fore wing with darker spot apically on the marginal and submarginal cells.

Head. $1.5 x$ wider than long when viewed dorsally (Figure 3); face, frons, vertex and gena punctateimbricate, with scattered short setae; shallow subantennal groove; frons with slight lateral protrusion above toruli; posterior margin of head slightly concave in dorsal view; occipital carina absent; malar space $0.33 \times$ height eye; clypeus $4.6 \times$ as wide as high, margin sinuate, distinct medial process (Figure 9); distance from lateral ocellus to eye margin $0.9 \times$ distance between lateral ocelli; scape $1.3 \times$ length pedicel; first flagellomere $1.06 \times$ as long as scape, $0.65 \times$ as long as second flagellomere.

Mesosoma. Propleuron rugulose medially, imbricate and with scattered short setae laterally, ventro-lateral carina weak; pronotum without angular process, rugulose and with scattered punctures; mesoscutum in lateral view rounded antero-dorsally, medial and lateral lobes strigate, with underlying punctate-imbricate sculpturing, with scattered short setae, admedial lines present (Figure 12); scutellum and axillae weakly strigate (Figure 19), with underlying punctate-imbricate sculpturing; metapostnotum scrobiculate, posterior margin distinctly convex (Figure 19); mesepisternum rugulose dorsally, smooth medially, rugose-punctate ventrally, with short setae, denser ventrally; mesepimeron broad, carinate; metapleuron rugulose dorsally, smooth medially, rugose-punctate ventrally with short setae; propodeum coarsely rugose, smooth medially and with a median dorso-ventral carina, posterior margin scrobiculate; hind coxa rugose dorsally, imbricate laterally, pubescence short, ovipositor guide on inner side, somewhat distal, pronounced ventral lobe on outer side; hind trochanter imbricate, pubescence short; prefemur on hind leg 

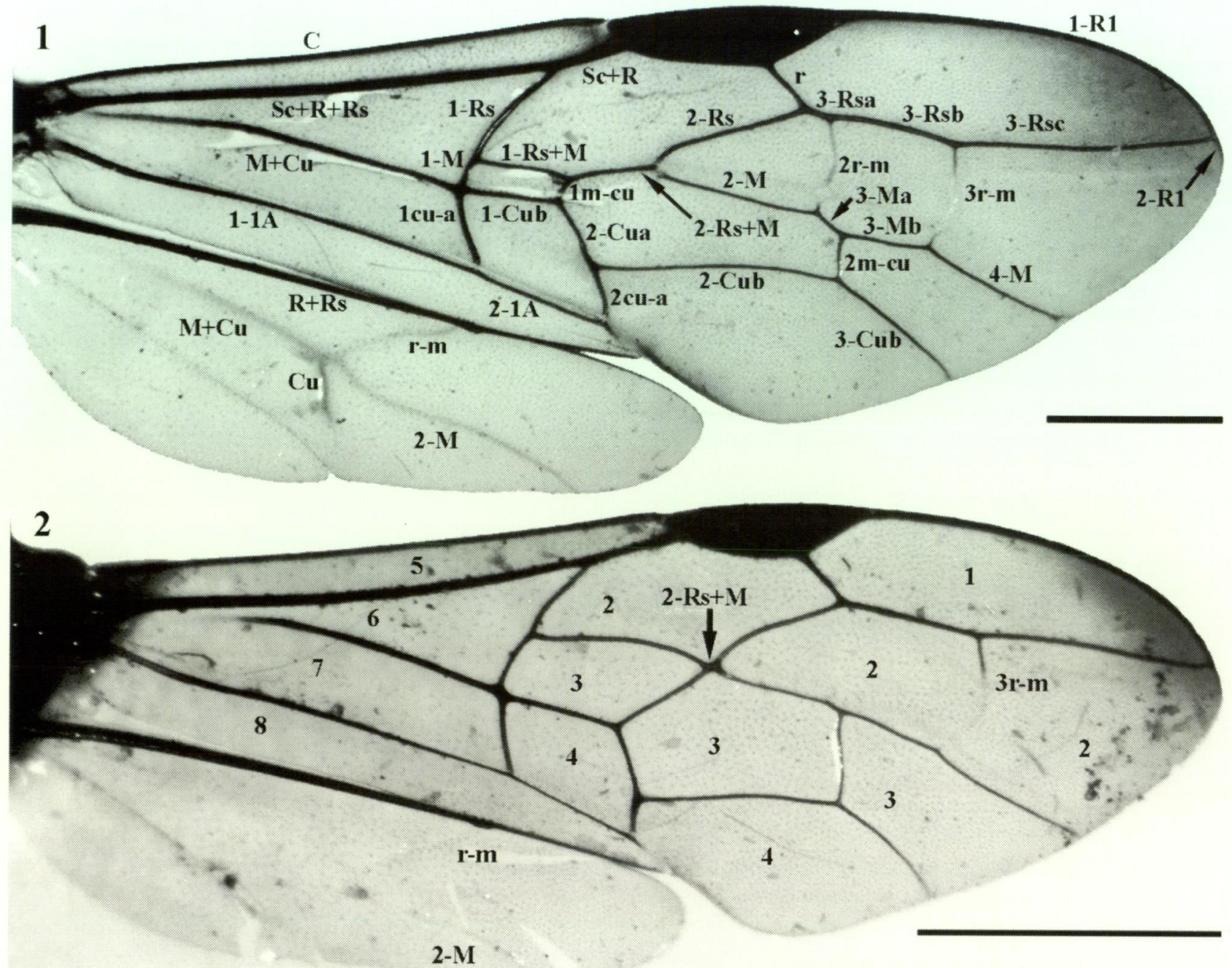

Figures 1-2 Wings of (1) A. houstoni sp. nov., holotype female; (2) P. davisi sp. nov., holotype female; cells are: $1=$ marginal, $2=$ submarginal, $3=$ discal, $4=$ subdiscal, $5=$ costal, $6=$ basal, $7=$ subbasal, $8=$ plical. Scale bars $=1 \mathrm{~mm}$.

present; hind femur imbricate, pubescence very short; hind tibia imbricate, pubescence short, with scattered emergent stout setae; hind femur $0.67 \mathrm{x}$ length hind tibia; hind tibia with ventro-apical pecten of short robust spines; hind tarsal segments $1-4$ with ventro-apical pecten of short robust spines, segment 1, $2.55 \mathrm{x}$ length segment 2; segment $2,1.8 \mathrm{x}$ length segment 3 ; segment $3,1.8 \times$ length segment 4 ; segment 4, $0.55 \times$ length segment 5 ; hind tarsal claw $0.7 \times$ length segment 5 ; fore wing vein $2-R s+M$ long, second discal cell elongate, veins $2 \mathrm{r}-\mathrm{m}$ and $3 \mathrm{r}-$ $\mathrm{m}$ pale brown, largely spectral medially (Figure 1); hind wing venation complete, $\mathrm{R}+\mathrm{Rs}, \mathrm{M}+\mathrm{Cu}, \mathrm{Cu}, \mathrm{r}-$ $\mathrm{m}$ and 2-M present (Figure 1), with 4 hamuli.

Metasoma. Clavate, $1.23 \times$ length of mesosoma; T1 and T2 broad, T1 smooth medially, weakly rugulose-punctate laterally, T2 weakly imbricate with a few scattered punctures; ovipositor $20.7 \mathrm{~mm}$.

\section{Male}

Unknown.

\section{Remarks}

This species is readily separated from the other Western Australian species by a number of character states. Aulacus houstoni (length $11.0 \mathrm{~mm}$ ) is intermediate in size between $A$. douglasi $(16.5 \mathrm{~mm})$ and $A$. momillani $(7.1 \mathrm{~mm})$. The medial and lateral lobes of the mesoscutum are strigate in A. houstoni, whereas the mesoscutal lobes of the other two species are rugose. Along with $A$. momillani, this species lacks the dark brown colouration on the costal, basal, submarginal, and marginal cells of the fore wing that is found in A. douglasi. It also differs in having a dark spot apically on the marginal and submarginal cells of the fore wing that is absent in the other two species. A number of eastern Australian species also have this apical spot on the fore wing.

Aulacus houstoni is known only from the holotype locality, Fitzgerald River National Park, Western Australia (Figure 29), and is named after the collector, Dr Terry Houston, Western Australian Museum. Nothing is known of its biology. 

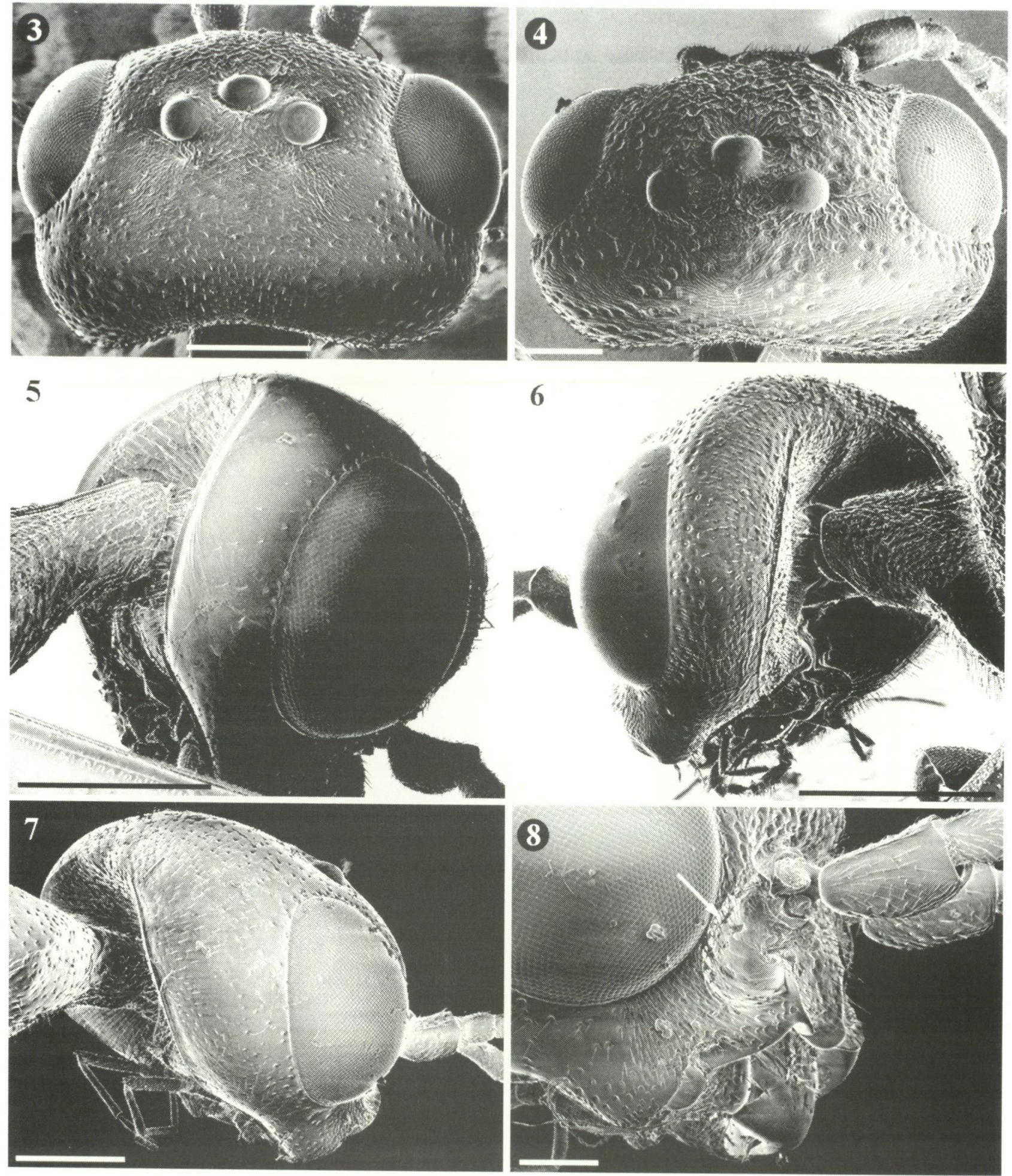

Figures 3-8 3-4. Dorsal view of head of (3) A. houstoni sp. nov., holotype female; (4) A. mcmillani sp. nov., holotype male. 5-7. Postero-lateral view of head of (5) P. curryi sp. nov., holotype female; (6) P. mouldsi sp. nov., holotype female; (7) $P$. davisi sp. nov., holotype female. 8. Lateral view of lower head showing subantennal groove of $P$. davisi sp. nov., holotype female. Scale bars $=3,5,7,500 \mu \mathrm{m} ; 4,8,200 \mu \mathrm{m} ; 6,1 \mathrm{~mm}$

Aulacus mcmillani sp. nov.

Figures 4, 27, 29

\section{Material Examined}

\section{Holotype}

§. "Kings Park. Emerged 4.i.1958 from larva coll. 2.xi.1957. R.P. McMillan." (WAM). Left antenna and right hind tarsi missing.

\section{Paratype}

Western Australia: $1 \delta$, same data as holotype (WAM). 

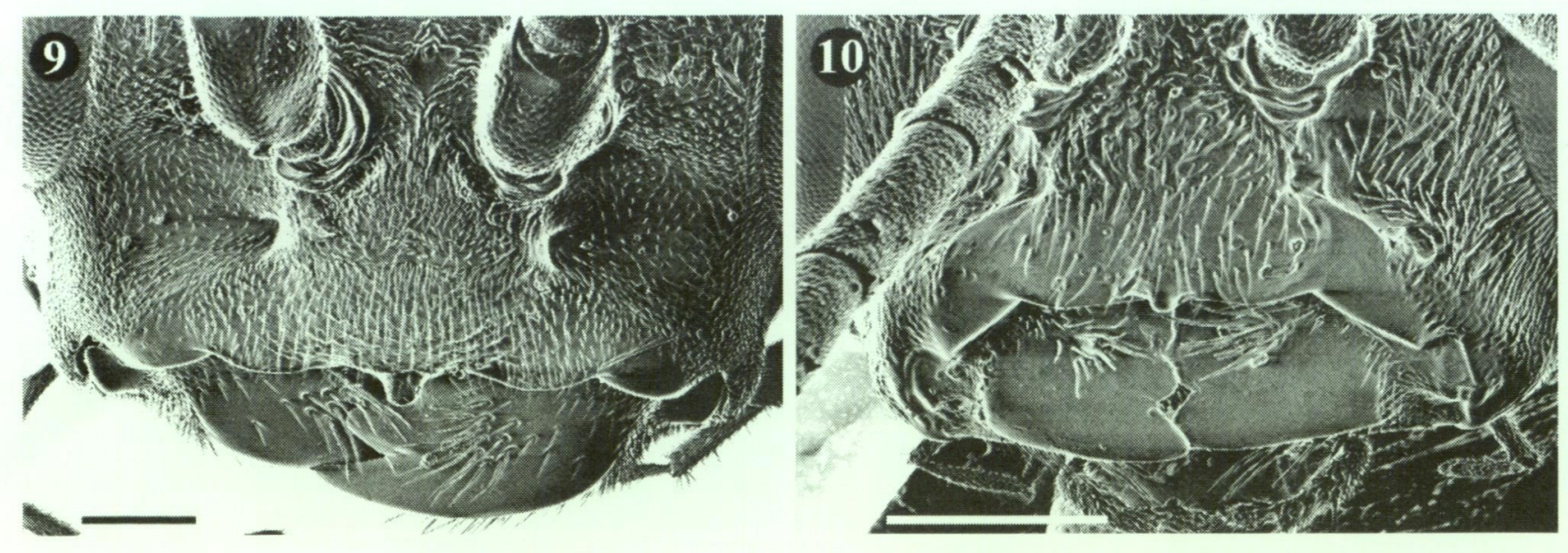

Figures 9-10 Clypeal region and mandibles of (9) A. houstoni sp. nov., holotype female; (10) P. mouldsi sp. nov., holotype female. Scale bars $=9,200 \mu \mathrm{m} ; 10,500 \mu \mathrm{m}$.

\section{Other specimens examined}

Western Australia: 1 , same data as holotype (WAM); 2 pupae, Kings Park, 17.xi.1957, R.P. McMillan (WAM).

\section{Male}

\section{Length. $7.1 \mathrm{~mm}$.}

Colour. Body and head dark brown, legs and metasoma yellow brown. Wings hyaline.

Head. Width:length 1.5 when viewed dorsally (Figure 4); distinct sub-antennal groove; face rugose, with scattered long setae; frons without lateral carina above toruli, punctate-imbricate, with scattered short setae; vertex punctate-imbricate, with scattered short setae; gena weakly rugulose, with scattered short setae; posterior margin of head not concave in dorsal view; occipital carina absent; malar space $0.3 \times$ height eye; clypeus $3.3 \times$ as wide as high, margin sinuate with small medial process; distance from lateral ocellus to eye margin $0.8 \mathrm{x}$ distance between lateral ocelli; scape $1.7 \times$ length pedicel; first flagellomere $0.7 \times$ as long as scape, 0.9 $\mathrm{x}$ as long as second flagellomere.

Mesosoma. Propleuron punctulate-imbricate, pubescence long, ventro-lateral carina present; pronotum without angular process, rugulose, with a few scattered punctures; mesoscutum in lateral view rounded antero-dorsally, medial and lateral lobes rugose, with a few scattered short setae, admedial lines present; scutellum and axillae rugose; metapostnotum rugose, posterior margin scrobiculate; mesepisternum rugose, with short pubescence; mesepimeron broad, scrobiculate; metapleuron rugose, with short pubescence; propodeum rugose dorsally, areolate laterally and medially, posterior margin weakly scrobiculate laterally; hind coxa strigate dorsally, rugose laterally, pubescence long laterally; hind trochanter imbricate, with scattered long setae; hind prefemur present; hind femur imbricate, with short pubescence; hind tibia imbricate, pubescence short, with scattered emergent stout setae; hind femur $0.67 \times$ length hind tibia; hind tibia with ventroapical pecten of short robust spines; hind tarsal segments 1-4 with ventro-apical pecten of short robust spines, segment $1,2.8 \times$ length segment 2; segment 2, $1.5 \times$ length segment 3; segment $3,1.3 \times$ length segment 4 ; segment $4,0.75 \times$ length segment 5 ; hind tarsal claw $0.6 \times$ length segment 5 ; fore wing vein $2-\mathrm{Rs}+\mathrm{M}$ long, second discal cell elongate, $2 \mathrm{r}-\mathrm{m}$ absent, 3r-m spectral medially; hind wing venation reduced, $\mathrm{M}+\mathrm{Cu}$ and $\mathrm{Cu}$ absent, with 3 hamuli.

Metasoma. Clavate, 1.65 x length of mesosoma; T1 and T2, narrow, smooth dorsally; basiparameres broad, imbricate (Figure 27); digitus broad, slightly longer than basiparameres (Figure 27).

\section{Female}

Note: The specimen has not fully emerged from the cocoon. Similar to male except: length $8.0 \mathrm{~mm}$; ovipositor at least $10.0 \mathrm{~mm}$ long; ovipositor guide on hind coxae present.

\section{Pupa}

$5.3 \mathrm{~mm}$ in length, exarate, covered with a pale brown testaceous cocoon.

\section{Remarks}

This species is the smallest of the Western Australian Aulacus species, and can be readily separated from the other species by its size and the characters in the key.

All known specimens were bred from cerambycid larvae (unknown species) collected in Kings Park, Perth, Western Australia (Figure 29). The species is named after the collector, R.P. McMillan.

\section{Pristaulacus Kieffer, 1900}

Aulacostethus Philippi 1873: 302. Type species: Aulacostethus rubiventer Phillipi, by monotypy 
(preoccupied by Waterhouse 1869 (Coleoptera), Uhler 1871 (Hemiptera-see Smith 2001). Townes 1950: 88; Townes 1951: 657; Crosskey 1953: 759 .

Aulacosthethus Schletterer 1889: 523. Misspelling of Aulacostethus.

Pristaulacus Kieffer 1900: 813. Type species: Pristaulacus chlapowskii Kieffer, designated by Kieffer 1903: 455. Kieffer 1903: 378, 382, 455; Kieffer 1904: 7; Schmiedeknecht 1907: 493, 501; Bradley 1908: 121, 126; Kieffer 1911: 215, 227; Kieffer 1912: 376; Schmiedeknecht 1914: 194; Hedicke 1930: 76; Schmiedeknecht 1930: 81; Hedicke 1939: 4; Oehlke 1983: 441; Koslov 1988: 243; Konishi 1990: 641; Aleeksev 1995: 39; Smith 2001: 277.

Deraiodontus Bradley 1901a: 29. No species included. Type species: Aulacus montanus Cresson, by subsequent designation, first included species by Bradley 1901b: 321. - (syn. Kieffer 1903: 382)

Oleisoprister Bradley 1901b: 324. Type species: Aulacus firmus Cresson, by original designation. - Kieffer 1903: 382; Bradley 1908: 121. (syn. Kieffer 1911: 227).

Aulacostathus Dalla Torre 1902: 1062. Misspelling of Aulacostethus.

Anaulacus Semenow 1903: 173. Type species: Aulacus sibiricola Semenow, by subsequent designation of Bradley 1908: 120. Preoccupied by MacLeay 1825 (Coleoptera) (see Smith 2001).

Semenowia Kieffer 1903: 382. New name for Anaulacus Semenow. Preoccupied by Weise 1889 (Coleoptera) (see Smith 2001). - Kieffer 1904: 720. (syn. of Odontaulacus Kieffer 1912: 365).

Odontaulacus Kieffer 1903: 382. Type species: Aulacus rufitaris Cresson, designated by Bradley 1908: 120. - Bradley 1908: 120; Kieffer 1911: 215; Kieffer 1912: 365; Hedicke 1939: 20; Aleeksev 1995: 39. (syn. of Aulacostethus Townes 1950: 88).

Semenovius Bradley 1908: 120. New name for Semenowia Kieffer. - Townes 1950: 88.

Tropaulacus Bradley 1908: 120. Type species: Tropaulacus torridus Bradley, by original designation. - Kieffer 1911: 215; Kieffer 1912: 362; Hedicke 1939: 17. (syn. of Aulacostethus Townes 1950: 88)

Pristaulacus (Neaulacus) Bradley 1908: 121. Type species: Aulacus occidentalis Cresson, by original designation. - (syn. Kieffer 1911: 227).

Interaulacus Bradley 1908: 120. Type species: Interaulacus kiefferi Bradley, by original designation. - Kieffer 1911: 215; Kieffer 1912 376; Hedicke 1939: 20. (syn. Smith 2001: 280).
Tetraulacinus Kieffer 1910: 350. No species included. Type species: Pristaulacus rufobalteatus Cameron, by subsequent monotypy, first species included by Kieffer 1911: 214. - Kieffer 1912: 363; Hedicke 1939: 17. (syn. of Aulacostethus Townes 1950: 88).

Psilaulacus Kieffer 1910: 350. No species included. Type species: Psilaulacus anmulatus Kieffer, by subsequent monotypy, first species included by Kieffer 1911: 215. - (syn. Kieffer 1912: 376).

Aulacosthetws Kieffer 1912: 370. Misspelling of Aulacostethus.

Aulacomastus Muesebeck and Walkley 1956: 333. Unnecessary new name for Aulacostethus Phillipi.

Odontacolus: Koslov 1988: 242. Misspelling of Odontaulacus.

\section{Diagnosis based on Australian species}

As for Aulacus except: each tarsal claw pectinate, with one basal tooth (sometimes difficult to see) and one or more medial teeth.

\section{Comments}

The genus Aulacostethus was erected by Philippi (1873), but Aulacostethus was preoccupied by a beetle and a hemipteran. In 1900, Kieffer erected Pristaulacus to include all taxa previously included in Aulacostethus. However, a degree of confusion continued for many years as a number of authors, notably Townes (1950) and Crosskey (1953), continued to use Aulacostethus.

As with Aulacus, early authors had not established the generic limits of Pristaulacus, so that a number of genera were erected to include specific variation. These included Anaulacus Semenow from Siberia, Deraiodontus Bradley, Oleisoprister Bradley, and Tropaulacus Bradley from North America, Odontaulacus Kieffer from South and North America, and Australia, Interaulacus Bradley from South America, Psilaulacus Kieffer from Mexico, and Tetraulacinus Kieffer from India. By 1912, Kieffer had included some 84 species in his world catalogue and synonymised Semenovius with Odontaulacus and Psilaulacus with Pristaulacus. Townes (1950) provided a degree of generic stability by placing Odontaulacus, Tropaulacus, and Tetraulacinus into synonymy with Aulacostethus, although he failed to recognise that Aulacostethus had been synonymised with Pristaulacus. Townes also erroneously synonymised Disaulacinus with Aulacostethus; Disaulacinus is now considered a synonym of Aulacus. Oehlke (1983) and others recognised only the genus Pristaulacus to define those aulacids with pectinate hind tarsal claws. In his recent catalogue, Smith (2001) included 106 species in Pristaulacus, including 16 from Australia. 

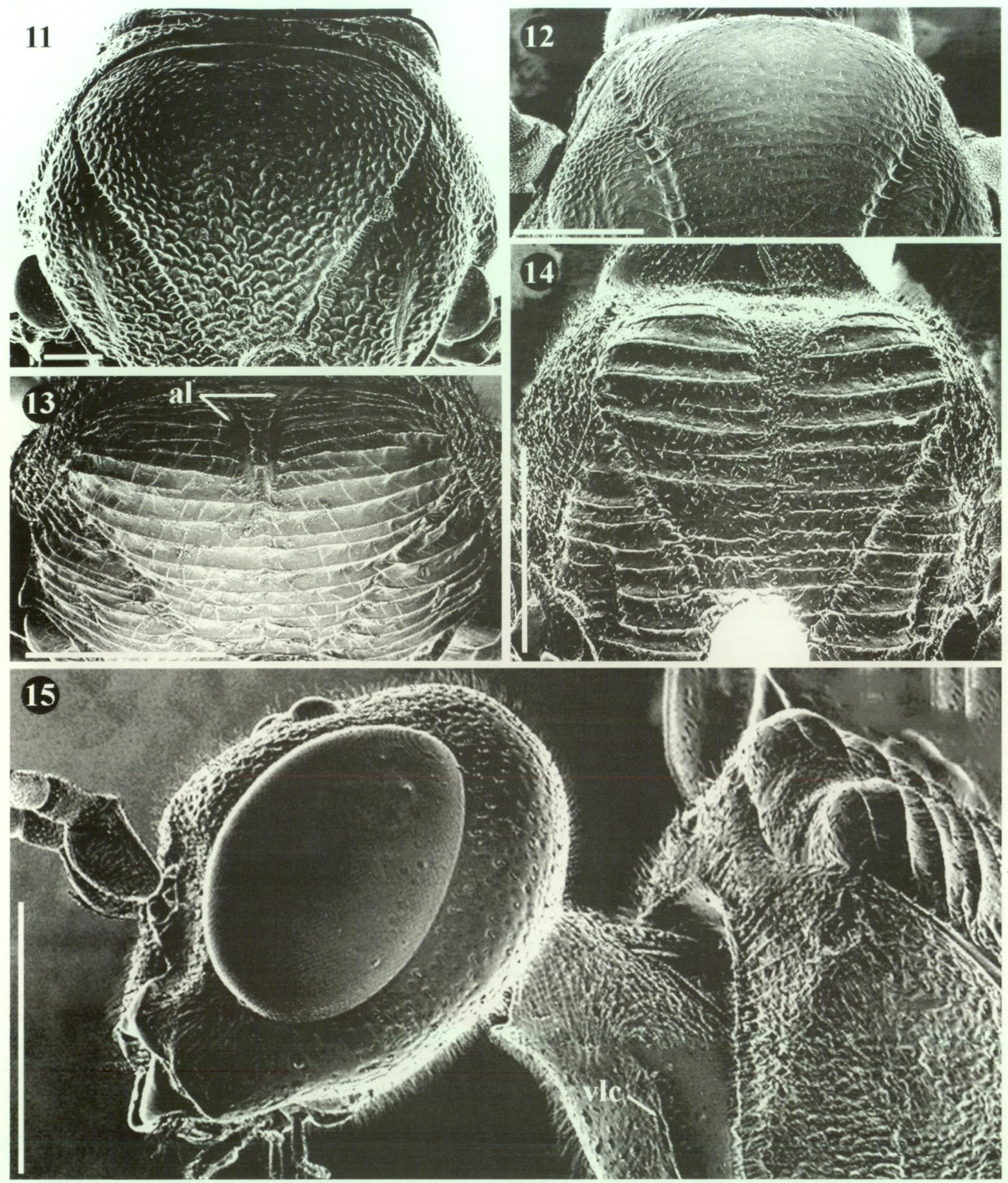

Figures 11-15 11-14. Dorsal view of mesoscutum of (11) A. douglasi sp. nov., holotype female; (12) A. houstoni sp. nov., holotype female; (13) P. curryi sp. nov., holotype female; al = admedial line; (14) P. mouldsi sp. nov., holotype female. 15. Lateral view of head and mesoscutum of $P$. mouldsi sp. nov., holotype female; vlc $=$ ventro lateral carina. Scale bars $=11-13,500 \mu \mathrm{m} ; 14-15,1 \mathrm{~mm}$.

Pristaulacus curryi sp. nov. Figures 13, 20, 23, 26, 28-29

\section{Material Examined}

Holotype

q. "Jarrahdale W. Aust., Ex E. microcorys, Feb
1974, S.J. Curry" (WADA). Right antenna missing.

\section{Paratypes}

Western Australia: 1 §, N Yanchep, 6.ii.1968, S.J. Curry (WADA); 1 ơ, Ludlow, 20.iii.1968, S.J. Curry (WADA); 2 $q$, Dwellingup, 24.ii.1970, S.J. Curry 
(WADA); 4 \& 8 , Jarrahdale, 21.1.1974, 5.). Curry (WADA).

\section{Female}

Length. $6.0(5.7-6.5) \mathrm{mm}$, excluding ovipositor. Colour. Body black. Scape, clypeus, legs and metasomal T1 and T2 light brown; wings hyaline except for a small fuscous spot at tip of fore wing.

Head. Width:length 1.2 when viewed dorsally; face rugose, pubescence short; sub-antennal groove smooth; frons rugose-punctate near toruli to punctate near ocelli, lateral carina above toruli, absent, with scattered short setae, denser near toruli; vertex and gena smooth, shiny except for a few scattered shallow punctures, each associated with a short seta; posterior margin of head slightly concave in dorsal view; occipital carina complete (Figure 5); malar space $0.3(0.26-0.33) \times$ height eye; clypeus $4.4(4.2-4.8) \times$ as wide as high, margin sinuate, with small medial process; distance from lateral ocellus to eye margin $0.46(0.4-0.5) \times$ distance between lateral ocelli; scape $1.7(1.6-1.75) \times$ length pedicel; first flagellomere $1.3(0.9-1.4) \times$ as long as scape, $1.24(1.09-1.36) \times$ as long as second flagellomere.

Mesosoma. Propleuron rugose, pubescence short, ventro-lateral carina present; pronotum without angular process, rugose; mesoscutum in lateral view angular antero-dorsally, medial and lateral lobes carinate with scattered short setae, admedial lines slightly curved (Figure 13); scutellum and axillae carinate (Figure 20); metapostnotum broad, depressed, rugose, scrobiculate posterior margin (Figure 20); mesepisternum rugose, with long pubescence; mesepimeron broad, scrobiculate; metapleuron rugose, with long pubescence; propodeum coarsely rugose, posterior margin coarsely scrobiculate; hind coxa rugulose, distinct flange-like ovipositor guide on inner side, distal (Figure 26); hind trochanter imbricate, with distinct groove, with scattered long setae; prefemur on hind leg present; hind femur imbricate, pubescence short; hind tibia imbricate, pubescence short, with scattered emergent stout brown setae; hind femur $0.82(0.79-0.86) \times$ length hind tibia; hind tibia with ventro-apical pecten of short robust spines; hind tarsal segments $1-4$ with ventro-apical pecten of short robust spines, segment $1,2.8(2.2-3.2) \times$ length segment 2 ; segment $2,1.4(1.35-1.60) \times$ length segment 3 ; segment $3,1.4$ (1.3-1.6) x length segment 4 ; segment 4, $0.7(0.6-0.8) \times$ length segment 5 ; hind tarsal claw pectinate, with one large medial and one small basal tooth (difficult to see), $0.5 \times$ length segment 5; fore wing rein 2-Rs+M long, second discal cell elongate, vein $2 \mathrm{r}-\mathrm{m}$ largely spectral; $3 \mathrm{r}-\mathrm{m}$ tubular in anterior third and posterior tenth, remainder spectral; hind wing venation complete, $\mathrm{R}+\mathrm{Rs}, \mathrm{M}+\mathrm{Cu}, \mathrm{Cu}, \mathrm{r}-\mathrm{m}$ and $2-\mathrm{M}$ present, with 2 hamuli.
Metasoma. Clarate, $1.07(1.05-1.10) \times$ length of mesosoma; $\mathrm{T} 1$ and $\mathrm{T} 2$, narrow, smooth (Figure 25); oripositor $4.7(3.4-5.2) \mathrm{mm}$.

Male

Similar to female except: length $6.7(6.5-6.8) \mathrm{mm}$; wings entirely hyaline; metasoma narrower; digitus about same length as basiparameres (Figure 28); basiparameres narrow and smooth, except shallow punctures, each associated with a somewhat stout seta (Figure 28).

\section{Remarks}

The male of this species is slightly larger than the female and can be distinguished from the female by the absence of the fuscous tip on the fore wings, as well as by having 13 antennal segments, typical of male aulacids.

Pristaulacus curryi can be readily distinguished from the other two Western Australian species by its small size. Both $P$. davisi and $P$. mouldsi have a body length of more than $10.0 \mathrm{~mm}$ compared with $6.0(5.7-6.5) \mathrm{mm}$ for $P$. curryi. Also, the fore wing vein $2-R s+M$ is short and the second discal cell is more or less quadrate in $P$. davisi (Figure 2) and $P$. mouldsi, whereas in $P$. curryi, vein $2-R s+M$ is long and the second discal cell is elongate (see Figure 1).

All specimens of P. curryi emerged from timber of various Eucalyptus species, jarrah (E. marginata), tallowwood (E. microcorys) and tuart (E. gomphocephala), although the beetle host is unknown. This species has been collected from a number of localities in south-western Western Australia (Figure 29), and has been named after the collector, Stephen Curry.

\section{Pristaulacus davisi sp. nov.} Figures 2, 7-8, 17, 21, 25, 29

\section{Material Examined}

\section{Holotype}

q. "Sawyer[s] Valley, W.A., Dec." (WADA). Left flagellomeres 7 to tip and right 8 to tip, front right femur and tarsi, mid tarsi, and hind tibiae and tarsi missing.

\section{Female}

Length. $10.0 \mathrm{~mm}$, excluding ovipositor.

Colour. Body brown, head, antennae, pronotum, and hind trochanters and femorae black, last few metasomal segments darker brown, wings hyaline, pale brown, fore wing costal cell darker.

Head. Width:length 1.25 when viewed dorsally; face rugulose, pubescence long; sub-antennal groove smooth, shiny (Figure 8); frons without lateral carina above toruli, shiny, punctate, with scattered short setae, denser and longer near toruli; 

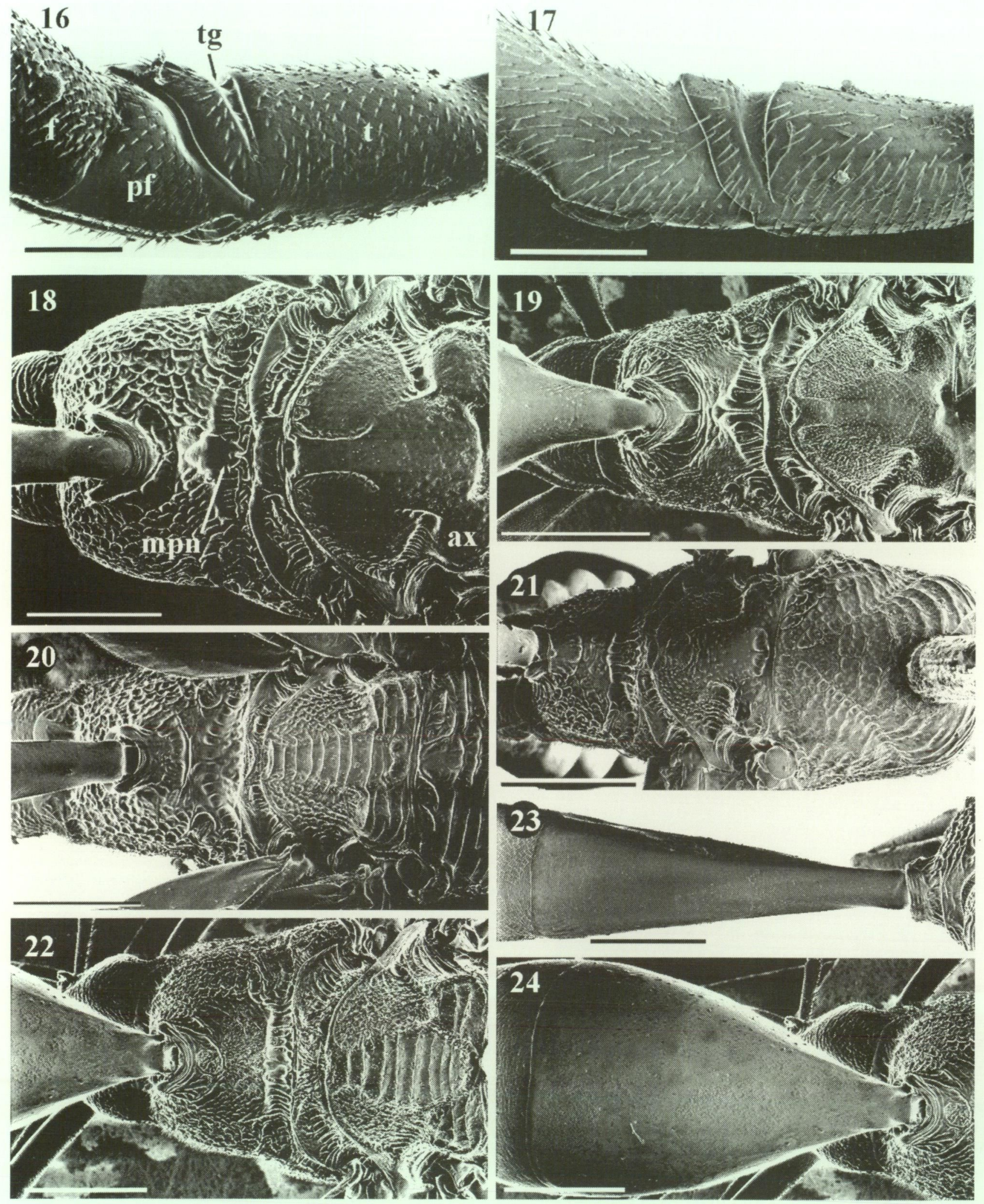

Figures 16-24 (16) Lateral view of hind trochanter, prefemur, and femur of A. douglasi sp. nov., holotype female; tg= trochanteral groove, $\mathrm{pf}=$ prefemur (trochantellus), $\mathrm{f}=$ femur. (17) Lateral view of hind trochanter and prefemur of $P$. davisi sp. nov., holotype female. Scale bars $=200 \mu \mathrm{m}$. Dorsal view of scutellum of (18) $A$. douglasi sp. nov., holotype female; sc = scutellum, ax = axilla, $\mathrm{mpn}=$ metapostnotum; (19) A. houstoni $\mathrm{sp}$. nov., holotype female; (20) P. curryi sp. nov., holotype female; (21) A. davisi sp. nov., holotype female; (22) P. mouldsi sp. nov., holotype female. Dorsal view of T1 and T2 of (23) P. curryi sp. nov., holotype female; (24) P. mouldsi sp. nov., holotype female. Scale bars = 16-17, $200 \mu \mathrm{m}$. 18-19, 21-22, 24, $1 \mathrm{~mm}$; 20, $23,500 \mu \mathrm{m}$. 
vertex and gena shiny, punctate, with scattered short setae; posterior margin of head not concave in dorsal view; occipital carina present laterally, absent medially (Figure 7); malar space $0.25 \times$ height eye; clypeus $5.0 \mathrm{x}$ as wide as high, with sinuate margin, small medial process present; distance from lateral ocellus to eye margin $0.65 \mathrm{x}$ distance between lateral ocelli; scape $1.6 \times$ length pedicel; first flagellomere $2.0 \times$ as long as scape, $0.75 \mathrm{x}$ as long as second flagellomere.

Mesosoma. Propleuron smooth, shiny, with scattered shallow punctures, each associated with a long seta, ventro-lateral carina present; pronotum without angular process, rugose-punctate in dorsal part to punctate in ventral part; mesoscutum in lateral view rounded antero-dorsally, medial and lateral lobes coarsely strigate, with scattered short setae, admedial lines not visible; scutellum and axillae strigate (Figure 21); posterior margin of metapostnotum scrobiculate, weakly convex (Figure 21); mesepisternum and metapleuron rugose, with long pubescence; mesepimeron broad, scrobiculate; propodeum rugose, almost areolate medially, posterior margin scrobiculate; hind coxa rugose with lateral striations dorsally, pubescence long laterally, ovipositor guide on inner side, distal, indicated by bulge on ventral surface (Figure 25); hind trochanter with broad groove (Figure 17), imbricate, pubescence long; prefemur indistinct
(Figure 17); hind femur imbricate, with short pubescence; hind tibiae and tarsi missing; fore wing vein $2-R s+M$ short, second discal cell more or less quadrate, vein $2 \mathrm{r}-\mathrm{m}$ almost absent except for slight node on medial vein (Figure 2); 3r-m tubular in anterior quarter, remainder spectral (Figure 2); hind wing venation reduced, veins $\mathrm{r}-\mathrm{m}$ and $2-\mathrm{M}$ spectral except for distal 2-M (Figure 2), with 3 hamuli.

Metasoma. Clavate, $1.5 x$ length of mesosoma; T1 and T2, narrow, smooth dorsally; ovipositor 8.0 $\mathrm{mm}$.

\section{Male}

Unknown.

\section{Remarks}

Pristaulacus davisi can be separated from P. curryi by its larger size, and from P. mouldsi by the hind wing venation, which is reduced (Figure 2). This species also has the metasomal $\mathrm{T} 1$ and $\mathrm{T} 2$ narrow whereas these are broad in $P$. mouldsi. Several eastern Australian species have a similar dark costal cell on the fore wing to that of $P$. davisi, but these species are quite different, particularly in size and colouration. They include $P$. cingulatus (Westwood) that is $9-12 \mathrm{~mm}$ in length and largely red-brown, $P$. lateritius (Shuckard) that is $12-20 \mathrm{~mm}$ in length and red-brown and black, and a number of undescribed taxa.
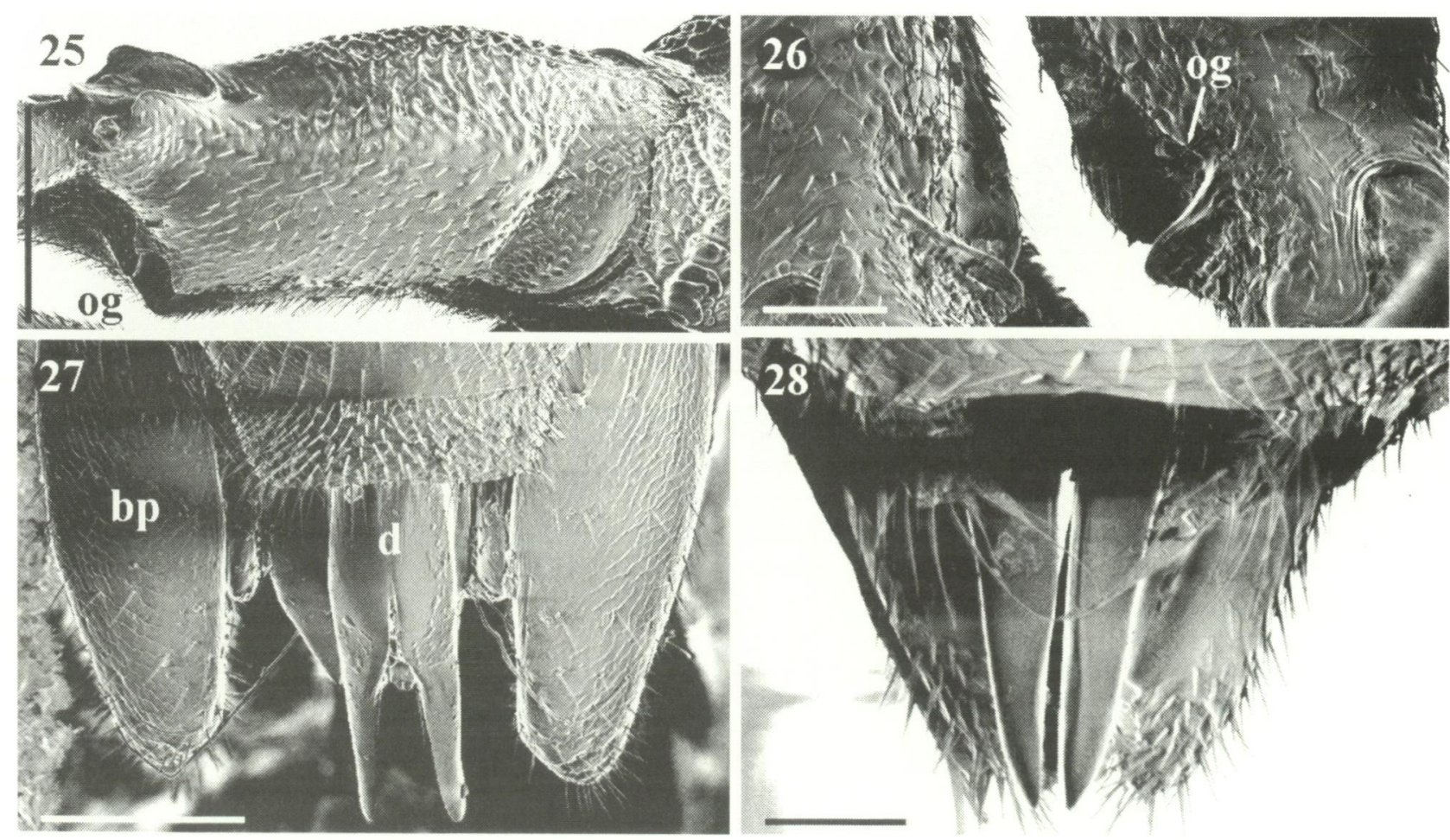

Figures 25-28 25. Lateral view of hind coxa showing position of ovipositor guide of $P$. davisi sp. nov., holotype female; og $=$ ovipositor guide. 26. Dorsal view of ovipositor guide on inner hind coxal surface of $P$. curryi sp. nov., holotype female; og = ovipositor guide. 27-28. Adeagus of (27) A. mcmillani sp. nov., holotype male; $\mathrm{bp}=$ basiparamere, $\mathrm{d}=$ digitus; (28) P. curryi sp. nov., paratype male. Scale bars $=25,500 \mu \mathrm{m} ; 26$, $100 \mu \mathrm{m} ; 27,200 \mu \mathrm{m} ; 28,50 \mu \mathrm{m}$. 
This species is named after Peter Davis, entomologist, Department of Agriculture, Western Australia. It is known only from the holotype locality, Sawyers Valley, Western Australia (Figure 29), and nothing is known of its biology.

Pristaulacus mouldsi sp. nov.

Figures 6, 10, 14-15, 22, 24, 29

\section{Material Examined}

\section{Holotype}

9. "Lake Cronin, W. Aust., 16.ii.1974, K.T. Richards" (WADA).

\section{Paratype}

Western Australia: 1 female, Norseman, [19]37. No other data. (WAM). Left hind leg missing except for coxa, right hind leg missing except for coxa and trochanter.

\section{Female}

Length. 10.8 (10.3-11.4) mm, excluding ovipositor.

Colour. Body dark brown to black, clypeus, legs, metasoma and ovipositor brown. Wings hyaline, pale brown.

Head. Width:length 1.75 when viewed dorsally; face rugose, pubescence long; sub-antennal groove present; frons without lateral carina above toruli, punctate-rugose, with short pubescence; vertex and gena punctate-imbricate with scattered short setae; posterior margin of head concave in dorsal view; occipital carina absent medially, weak laterally (Figure 6); malar space $0.3 \times$ height eye; clypeus $6.75 \mathrm{x}$ as wide as high, margin sinuate, with small medial process (Figure 10); distance from lateral ocellus to eye margin $0.7 \times$ distance between lateral ocelli; scape 1.05 (1.0-1.1) x length pedicel; first flagellomere $1.1(1.0-1.2) \times$ as long as scape, 0.65 $(0.6-0.7) \times$ as long as second flagellomere.

Mesosoma. Propleuron punctate, pubescence long laterally, ventro-lateral carina flange-like (Figure 15); pronotum without angular process, rugose; mesoscutum in lateral view angular antero-dorsally (Figure 15), medial and lateral lobes carinate with scattered short setae, admedial area depressed (Figures 14-15); scutellum and axillae carinate (Figure 22); metapostnotum narrow, scrobiculate, posterior margin straight (Figure 22); mesepisternum rugose with long pubescence; mesepimeron broad, scrobiculate; metapleuron rugose, with long pubescence; propodeum rugose, a few striations dorsally, posterior margin scrobiculate, hind coxa punctate with a few lateral striations dorsally, rugose laterally, pubescence long laterally, ovipositor guide on inner side, distal, almost at apex; hind trochanter imbricate, with distinct groove, with scattered short setae; hind femur imbricate, pubescence short; hind tibia imbricate, pubescence short, with scattered emergent stout setae; prefemur on hind leg present; hind femur $0.8 \times$ length hind tibia; hind tibia with ventro-apical pecten of very short robust spines; hind tarsal segments $1-4$ with ventro-apical pecten of short robust spines, segment $1,3.2 x$ length segment 2 ; segment $2,1.3 \times$ length segment 3 ; segment $3,1.8 \times$ length segment 4 ; segment $4,0.6 \times$ length segment 5 ; hind tarsal claw with two medial and one basal teeth (this difficult to see), $0.6 \times$ length segment 5; fore wing vein $2-\mathrm{Rs}+\mathrm{M}$ short, second discal cell more or less quadrate, vein $2 \mathrm{r}-\mathrm{m}$ absent, $3 \mathrm{r}-\mathrm{m}$ tubular in anterior third, remainder spectral; hind wing venation reduced, veins $r-m$ and $2-M$ spectral, with 2 hamuli.

Metasoma. Clavate, $1.0(0.9-1.1) \times$ length of mesosoma; T1 and T2, broad, smooth except for a few shallow punctures laterally (Figure 24); ovipositor $8.0(7.5-8.5) \mathrm{mm}$.

Male

Unknown.

\section{Remarks}

Pristaulacus mouldsi is the only Western Australian species with the metasomal $\mathrm{T} 1$ and $\mathrm{T} 2$ broad. It has been collected from two localities in the central, south-west of Western Australia (Figure 29), and is named after Max Moulds, formerly Collection Manager, Entomology at the Australian Museum. Nothing is known of the biology of this species.

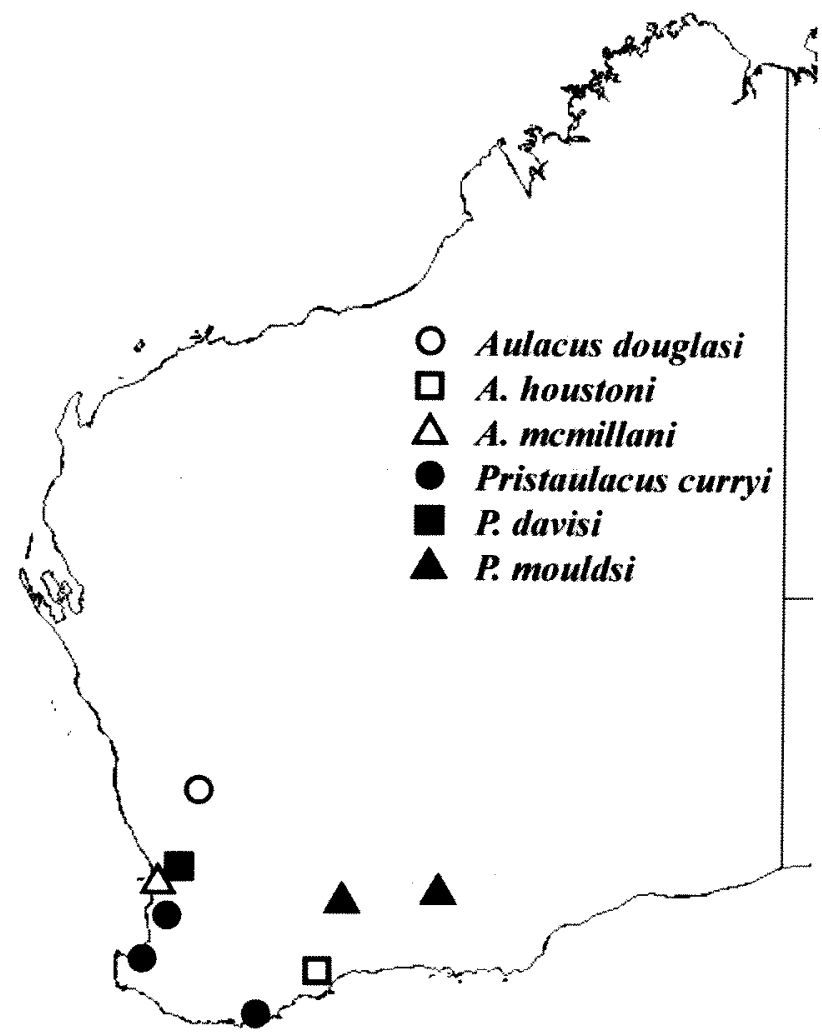

Figure 29 Distribution map of Western Australian Aulacidae. 


\section{ACKNOWLEDGEMENTS}

We thank the curators of the collections listed above for the loan of specimens, and the staff of Adelaide Microscopy, The University of Adelaide, for access to the FESEM. This work was supported by a grant from the Australian Biological Resources Study and a Small ARC grant to JTJ and ADA.

\section{REFERENCES}

Achterberg, C. van (1979). A revision of the Subfamily Zelinae auct. (Hymenoptera, Braconidae). Tijdschr. Ent. 122: 241-479.

Alekseev, V. N. (1995). Evanioidea, pp. 37-45. In Lehr, P.A., ed., [Keys to Insects of Russian Far East in Six Volumes. Vol. IV. Neuropteroidea, Mecoptera, Hymenoptera. Part 2. Hymenoptera], Vladivostok, Dal'nauka, 599 pp.

Bradley, J. C. (1901a). The Evaniidae of America north of Mexico. Ent. Student 2: 28-3 1.

Bradley, J. C. (1901b). The Evaniidae of America north of Mexico. Trans. Am. ent. Soc. 27: 319-330, pl. XI.

Bradley, J. C. (1908). The Evaniidae, ensign-flies, an archaic family of Hymenoptera. Trans. Am. ent. Soc. 34: 101-194, plates V-XV.

Carlson, R. W. (1979). Aulacidae, pp. 1111-1115. In Krombein, K.V., P.D. Hurd, Jr., D.R. Smith, and B.D. Burks, eds. Catalog of Hymenoptera in America North of Mexico. Volume 1. (Smithsonian Institution Press, Washington, D.C.).

Crosskey, R. W. (1951). The morphology, taxonomy, and biology of the British Evanioidea (Hymenoptera). Trans. R. ent. Soc., Lond. 102: 247-301.

Crosskey, R. W. (1953). Two new species of Aulacostethus Philippi and a new species of Aulacus Jurine, from Australia, together with a key to the Australian species of Aulacostethus (Hymenoptera: Aulacidae). Ann. Mag. nat. Hist. (12) 6: 758-766.

Cushman, R. A. (1929). New species of ichneumon-flies and taxonomic notes. Proc. U. S. natn. Mus. 76: 1-18.

Dahlbom, G. (1837). Species Aulaci Generis in Scandinavia habitantes. Isis, Jena 3: 173-177.

Dalla Torre, C. G. de. (1902). Catalogus Hymenopterorum hucusque descriptorum systematicus et synonymicus, Volumen III: Trigonalidae, Megalyridae, Stephanidae, Ichneumonidae, Agriotypidae, Evaniidae, Pelecinidae. Pars II., pp. 545-1141. Lipsiae.

Gauld, I. D. (1995). Aulacidae, pp. 192-193. In Hanson, P.E. and I.D. Gauld, eds., The Hymenoptera of Costa Rica. (Oxford University Press, Oxford).

Gauld, I. D. and Bolton, B (eds.) (1996). The Hymenoptera. 2nd. ed. (Oxford University Press, Oxford).

Harris, R .A. (1979). A glossary of surface sculpturing. Calif. Dept. Food Agric., Bureau Entomol., Occ. Papers 28: 1-28.

Hedicke, H. (1930). 16. Ordnung: Hautflüger, Hymenoptera, Abteilg. XI, 246 pp. In Brohmer, P., P. Ehrmann, and G. Ulmer, eds., Die Tierwelt Mitteleuropas, Ein Handbuch zu ihrer Bestimmung als Grundlage für faunistisch-zoogeographische Arbeiten. Band V, Insekten.2. Teil. Leipzig.
Hedicke, H. (1939). Aulacidae. In Hedicke H., ed. Hymenopterorum Catalogus, Pars 10. (Dr. W. Junk, Gravenhage)

Jennings, J. T. (2001). Aulacidae. [Checklist of Australian species] Australian Faunal Directory, Australian Biodiversity Information Facility, Environment Australia. (http://www.environment.gov.au/abrs/ abif-fauna).

Jennings, J. T. and Austin, A. D. (1994). Revision of the genus Crassifoenus Crosskey (Hymenoptera: Gasteruptiidae: Hyptiogastrinae), with a description of a new species from Western Australia. Rec. West Aust. Mus. 16: 575-591.

Jennings, J. T. and Austin, A. D. (2000). Higher-level phylogeny of the Aulacidae and Gasteruptiidae (Hymenoptera: Evanioidea), pp. 154-164. In Austin, A.D. and M. Dowton, eds., Hymenoptera. Evolution, Biodiversity and Biological Control. (CSIRO Publishing, Collingwood, Australia).

Jennings, J. T. and Austin, A. D. (in press). Adult feeding in aulacid and gasteruptiid wasps (Hymenoptera: Aulacidae: Gasteruptiidae), with a review of their general biology, host relationships and systematics. In Rajmohana, K. ed., Biology of the Hymenoptera. University of Calicut, Kerala, India.

Jennings, J. T., Austin, A. D. and Stevens, N. B. (in press). Species of the wasp genus Aulacus Jurine (Hymenoptera: Aulacidae) endemic to South Australia. Trans. R. Soc. S.A.

Jurine, L. (1801). Nachricht von einen Neuen Entomolischen Werks, des Hrn. Prof. Jurine in Geneve. Intellig. Litt.-Z., Erlangen 1: 161-165.

Jurine, L. (1807). Nouvelle Méthode de Classer les Hyménoptères et les Diptères. Hyménoptères. Tome Premier. Geneve. 319 pp.

Kieffer, J. -J. (1900). Note sur le genre Pristaulacus Kieff. [Hymén.]. Bull. Soc.ent. Fr. 1900: 338-339.

Kieffer, J. -J. (1903). Les Evaniides. In André, E., Species des Hyménoptères d'Europe and d'Algérie. Volume 7, part 2, pp. 347-482. Paris.

Kieffer, J.-J. (1904). Description de Stéphanides ed d'evaniides nouveaux. Bull. Soc. d'Hist. Nat. Metz 11: $1-30$.

Kieffer, J. -J. (1910). Diagnoses de nouveaux genres d'Aulacinae (Hym.). Bull. Soc.ent. Fr. 1910: 350.

Kieffer, J. -J. (1911). Étude sur les Évaniides exotiques (Hym.) du British Museum de Londres. Ann. Soc.ent. Fr.80: 151-230.

Kieffer, J. -J. (1912). Hymenoptera, Ichneumonidae, Evaniidae. Das Tierreich, 30: 1-431.

Konishi, K. (1990). A revision of the Aulacidae of Japan (Hymenoptera, Evanioidea). Jpn. J. Ent. 58: 637-655.

Koslov, M. A. (1988). Aulacidae, pp. 242-244. In Medvedev, G.S., ed. [Keys to the Insects of the European Part of the USSR], Vol. III, Hymenoptera, Part VI Symphyta. Akademia Nauk SSSR, Zoologischkie Institut, 267 pp. [Translation, 1994, E.J. Brill, Leiden, 432 pp.]

Mason, W. R. M. (1993). Chapter 11. Superfamilies Evanioidea, Stephanoidea, Megalyroidea, and Trigonalyoidea, pp. 5 10-5 20. In Goulet, H. and J.T. Huber, eds., Hymenoptera of the World: An Identification 
Guide to Families. (Research Branch, Agriculture Canada Publication 1894/E).

Muesebeek, C. F. W. and Walkley, L. M. (1956). Type species of the genera and subgenera of parasitic wasps comprising the superfamily Proctotrupoidea (order Hymenoptera). Proc. U. S. natn. Mus. 105: 319419.

Naumann, I. D. (1991). Chapter 42. Hymenoptera (Wasps, bees, ants, sawflies), pp. 916-1000. In Naumann, I., ed. The Insects of Australia, A textbook for Students and Research Workers. Volume II. (Melbourne University Press).

Oehlke, J. (1983). Revision der europäischen Aulacidae (Hymenoptera-Evanioidea. Beitr. Ent. 33: 439-447.

Philippi, R. A. (1873). Chilenische insekten. Stettin. ent. Ztg. 34: 296-316.

Provancher, A. L. (1882). Faune Canadienne, Hyménoptéres, additions et corrections. Naturaliste can. 13: 289-31 1.

Schletterer A. (1889). Die Hymenopteren-Gruppe der Evaniiden. III. Abteilung. Amalen des K. K. Naturhistorischen Hoftnuseums, Separatabdruck aus band IV pp. 373-546, plates XIX - XXII. [Publication date also given as 1890]

Schmiedeknecht, O. (1907). Die Hymenopteren Mitteleuropas nach ihren Gattungen und zum grossen tiel auch nach ihren arten analytisch bearbeitet. Jena. 904 pp.
Schmiedeknecht, O. (1914). Die Schlupf-u. Brackwespen (Ichneumonidea), pp. 115- 256. In Schröder, C., ed., Die Insekten Mitteleuropas inbesondere Deutschlands. Band II, Hymenopteren, Zweiter Teil. Stuttgart. $256 \mathrm{pp}$.

Schmiedeknecht, O. (1930). Die Hymenopteren Nordund Mitteleuropas rnit Einschluss von England, Südschweiz, Südtirol und Ungarn, nach ihren Gattungen und zum Grossen Teilauch nach ihren Arten Analytisch Bearbeitet Zweite, Gänzlich Umgearbeitete Auflage. Jena, 1062 pp.

Semenow, A. (1903). De novo Evaniidarum genere (Hymenoptera). Rev. Russe ent. No. 3, 4: 173.

Sharkey, M. (1988). Ichneumonoid wing venation. Ichnews 11: 2-12.

Smith, D. R. (2001). World catalog of the family Aulacidae (Hymenoptera). Contrib. Ent., Int. 4: 263-319.

Townes, H. K. (1950). The Nearctic species of Gasteruptiidae (Hymenoptera). Proc. U. S. natn. Mus. 100: 85-145.

Townes, H. K. (1951). Aulacinae, pp. 657-660. In Muesebeek, C.F.W., K.V. Krombein, and H.K. Townes, eds. Hymenoptera of America North of Mexico, Synoptic Catalog. United States Department of Agriculture, Agriculture Monograph No. 2, 1420 pp.

Manuscript received 20 June 2003; accepted 16 January 2004 